\title{
DANGEROUS FRONTIERS IN CORPORATE GOVERNANCE
}

\author{
Thomas Clarke \\ UTS Sydney
}

\begin{abstract}
The historical evolution of corporate governance is considered, highlighting the different eras of governance, the dominant theoretical and practical paradigms, the reformulation of paradigms and counter paradigms. Two alternative and sharply contrasting theorizations, one collective and collaborative (the work of Berle and Means), the other individualistic and contractual (agency theory and shareholder value) are focused upon. The explanatory potential of Blair and Stout's team production theory is elaborated, and its conception of the complexity of business enterprise, with a mediating hierach (the board of directors) securing a balance between the interests of different stakeholders. The potential for reform of corporate purpose, corporate governance and directors' duties is examined with reference to the UK Modern Company Law Review. The impact of the intensification of the financialization of corporations is analysed, with the increased emphasis upon short-termism. The origins of the global financial crisis in shareholder value orientations is explored, and the continuing reverberations of the crisis. Finally the imperative of the advance of sustainable enterprise is argued, and the critical changes necessitated in corporate purpose and directors' duties.
\end{abstract}

\section{Keywords}

Corporate governance; directors duties; agency theory and shareholder value; team production theory; financialization; financial crisis; short termism; sustainability.

\section{Biography}

Thomas Clarke is Professor of Management and Director of the Centre for Corporate Governance at UTS Sydney. He has wide interests in international and comparative corporate governance; corporate governance in the finance sector; and corporate social responsibility and sustainability; and boards and directors research. He has published International Corporate Governance, London: Routledge (second edition 2015); and with Douglas Branson edited The Sage Handbook of Corporate Governance, London: Sage 2012. 


\section{DANGEROUS FRONTIERS IN CORPORATE GOVERNANCE}

\section{Thomas Clarke}

\section{Introduction}

In reality corporate governance is one of the most interesting, exciting and potentially dangerous disciplines. As corporate governance has moved through different eras, the paradigmatic challenges and responses often have proved heroic in dimensions. Somehow all of this vitality has in recent decades been largely reduced to an endless series of codes and templates, often inspired by the constrictions of agency theory. Boards of directors are an essential part of the DNA of corporations, and corporate governance is a vital means of fulfilling the strategic potential of corporations. However the dangers of corporate failure are very real if corporate governance goes awry. This can impact seriously upon the economy and society. Weaknesses in governance and regulation in financial institutions delivered the recent global financial crisis (Clarke 2010). Any failure in corporate governance in response to the present sustainability challenge will have far more serious consequences. This analysis examines dominant paradigms in corporate governance over the last century, highlighting the contest between Berle and Means conception of the corporation with a social purpose, and the narrower concerns of agency theory. The reform of corporate purpose, corporate governance and directors' duties is critically considered in the context of an enveloping financialization that is increasingly driving short termism (Lazonick 2012; Clarke 2014). How corporate governance may be transformed to contribute to averting environmental disaster, and to the achievement of sustainable enterprise is the most demanding and dangerous frontier of all.

\section{Epoch Making Paradigmatic Challenges in Corporate Governance}


Corporate governance has evolved through a series of epoch making paradigmatic challenges. Bob Tricker who pioneered the contemporary research in corporate governance $(1988 ; 2012)$ has suggested that three distinct eras can be identified:

- 19th C Entrepreneurship

- 20thC Management

- 21st C Governance

The 19 th century was a time of great entrepreneurs advancing technologies and products, and building businesses in enterprises they owned and controlled with a personal domination. As business enterprises increased in scale and complexity the need for more specialized management and for enhanced sources of investment led to the separation of ownership and control, and boards of directors became more firmly established in the $20^{\text {th }}$ century to pursue the best interests of the company and provide accountability for performance. In the $21^{\text {st }}$ century the need for wider accountability and responsibility of business has become apparent with the realization of the profound environmental and social impact of corporations. In addition there is the increasing influence of the rise of vast investment institutions the beneficiaries of whom represent large sections of the community including superannuation, insurance and mutual funds, and the recognition effective governance is required for the security of investments.

Managers operating in a particular era typically see the world through one overarching paradigm, within which separate frames of reference, metaphors and perspectives that they use stand in some coherence to each other, but differ radically from those in use in preceding and succeeding eras. Using new frames of reference or seeing through the assumptions of different forms means that the managerial and organizational world not only looks different, it becomes different (sometimes presented as the social construction of reality (Berger and Luckmann 1966). In any system that is ecologically interdependent if you change any paradigmatic part then you change the whole. When there is sufficient change and fluidity in the system then we can speak of a paradigm shift, the period when a shift occurs from one paradigm to the next new paradigm. In these circumstances uncertainty and ambiguity will apply. Paradigm shifts are more 
challenging today because the pace of social, economic and technological change is more rapid, and the impact of business on the environment and society is more profound. Multiple technological breakthroughs, shortening product life cycles along global value chains, and rapidly changing markets are accelerating the pace of paradigm shifts, while serious questions are being raised concerning the sustainability of business enterprise (Clarke and Clegg 2000).

The search for coherent new paradigms is a vital task in corporate governance:

- A discipline that has become identified almost solely with endless templates for compliance and regulation;

- A discipline overwhelmed by the constrictions of Agency Theory (Weinstein 2012);

- A discipline neglectful of diversity, creativity and innovation;

- A discipline unaware of the impact of corporate governance upon the intensification of inequality (Ireland 2005);

- A discipline with a narrow focus on empirical studies of abstracted variables and bereft of attempts at holistic explanations of integrated and inter-related social and economic institutions and systems.

- A discipline ill-equipped to deal with the urgent imperative for corporate governance to deliver sustainable enterprise (Clarke 2015).

\section{FIGURE 1}

\section{THE EVOLUTION OF CORPORATE GOVERNANCE}

The evolution of corporate governance is portrayed in Figure 1 that highlights the different eras of governance, the dominant theoretical and practical paradigms, the reformulation of paradigms and counter paradigms.

\section{Berle and Means and the Collective Nature of the Corporation}


An emerging collective conception of the corporation is conveyed in the early work of Berle and Means (1932) who identified the collective nature of the corporate entity, the importance of managing multi-dimensional relationships, and the increasing accountability of the corporate entity with profound obligations to the wider community. Paradoxically Berle and Means left an ambiguous legacy (Cioffi 2011),that was subsequently interpreted in two alternative and sharply contrasting theorizations, one collective and collaborative, the other individualistic and contractual (Weinstein 2012). Throughout much of the $20^{\text {th }}$ century the large modern enterprise was represented as a social institution, an organisation formed through collective action, and technological advance (Galbraith, 1952; 1967; Chandler, 1977). Chandler is identified with the conception of the large corporation as an integrated, unified, collective entity that could not possibly be reduced to the sum of individuals it comprises (Weinstein 2012). Then in the later decades of the $20^{\text {th }}$ century the view of the enterprise as a simple contractual arrangement, a nexus of contracts, and a mode of interaction between individuals became ascendant, providing the theoretical framework for the ultimately hegemonic agency theory and its insistence on shareholder primacy and shareholder value (Weinstein 2012; Aglietta and Reberioux 2005; Coase, 1960; Alchian and Demsetz,1973; Jensen and Meckling, 1976).

The modern corporation as typified by Berle and Means manifested the separation of ownership and control, where professional managers were able to determine the direction of the enterprise and shareholders had "surrendered a set of definite rights for a set of indefinite expectations" (Berle and Means 1932:244). After the New Deal and the end of the Second World War, managers seized the opportunities newly open to them, and many US corporations grew massively in scale and market domination achieving a pre-eminent position in the world economy. A new managerial mode of coordination of enterprise, technology, and planning had arrived transcending the market (Chandler 1977).

This was the era of Galbraith's New Industrial State (1967) in which corporate growth and brand prestige appeared to displace profit maximisation as the goal of technocratic managers (Henwood 1998:259). In a technocratic milieu the shareholder was rendered "passive and functionless, remarkable only in his capacity to share without effort or 
appreciable risk, the gains from growth by which the technostructure measures its success" (Galbraith, 1967:356). This Galbraithian idyll was disintegrating by the time of the severe recession of the early 1970s, with the incapacity of US corporations to compete effectively with Japanese and European products in important consumer market sectors, accompanied by a push by Wall Street towards conglomerate formation in the interests of managing multiple businesses by financial performance. "Over time purely financial interests have increasingly asserted their influence over hybridised giant corporations" (Henwood 1998:262).

\section{The Grim Hegemony of Agency Theory}

While the nexus of contracts theory preceded agency theory, and was the intellectual foundation upon which it was based, it was the cruder aspects of agency theory that became the dominant paradigm in business and law. The insistence on the collective and public nature of the new corporations which Berle and Means convincingly made and others including Galbraith and Chandler developed, invited a response from economists and lawyers who retained a belief in private property, free markets and shareholder rights. This was a determined and successful effort to impose "the reprivatisation of the corporation" (Ireland, 2001; Weinstein 2012).

Management theory and practice for some decades has been overwhelmed by this narrow and constricted view of the modern corporation. Agency theory is often assumed to be eternal, universal and unquestionable in its explanation of the essence of the nature of the corporation. In fact agency theory is of quite recent construction, heavily focused on the Anglo-American business world, and is profoundly questionable. All of the sophistication, rich diversity, nuances and insights of management scholars and the experience and wisdom of management practitioners have been displaced by the rigid simplicity of the assumptions of agency theory in recent decades (Ghoshal 2005). This one-dimensional management, with its self-validating hypotheses, as Marcuse warned, has populated the management journals, and infused management discourse. 
Jensen and Meckling (1976) Theory of the Firm: Managerial Behaviour, Agency Costs and Capital Structure remainss one of the most cited economic articles of the last four decades. It sets out a new theory of the firm firmly triangulated between 1) property rights, 2) agency and 3) finance. The singular concern for agency theory is that the 'agents' (managers) represent the interests of the 'principals' (shareholders). The new theory of the firm aims to go beyond standard neoclassical theory's distancing treatment of the firm as a 'black box,' and offers a stringent alternative to the managerial theories of Galbraith, Chandler and others, in which the objective of the managerial firm was determined to be maximisation of growth or size, and fulfilment of a wide spectrum of economic, technological, social and political goals.

Agency theory has become "a cornerstone of ... corporate governance" (Lan \& Heracleous, 2010). Agency theory is often regarded not only as the dominant current interpretation, but as an eternal and universal explanation, but is very much a product of the Anglo-American corporation and capital market. Rooted in finance and economics, it has somehow managed to penetrate not only policy and practice, but the essential understanding of corporate law regarding directors' duties. Not only does agency theory dangerously over-simplify the complexities of business relationships and decisions, it damagingly demands a focus on a single objective. Agency theory asserts shareholder value as the ultimate corporate objective that managers are incentivized and impelled to pursue: "The crisis has shown that managers are often incapable of resisting pressure from shareholders. In their management decisions, the short-term market value counts more than the long-term health of the firm" (Segrestin \& Hatchuel, 2011).

The mythology of shareholder value has proved one of the most debilitating ideologies of modern times. The pursuit of shareholder value has damaged and shrunk corporations, distracted and weakened managers, diverted and undermined economies, and, most paradoxically, neglected the long term interests of shareholders (Stout 2012; Clarke 2014; Lazonick 2014). An unfortunate lacuna in corporate law was filled by the simplistic tenets of agency theory, which has promulgated enduring myths of shareholder primacy that have been misconstrued as authentic legal interpretations of directors' duties, and often guided directors with increasingly narrow and damaging corporate objectives. The tenets of shareholder value are portrayed as eternal, universal, 
and unarguable when they are of recent origin, exclusive to Anglo-American regimes, and profoundly contentious. (Blair and Stout 1999; Stout 2012; 2013; Lazonick 2012; 2013;2014; Weinstein 2013; Clarke 2009; 2012; 2013; 2014; Aglietta and Reberioux 2005)

Among the central defects of agency theory as presently interpreted are that:

- Agency theory focuses on an oversimplification of complex financial and business reality

- Agency theory damagingly insists upon the single corporate objective of shareholder value

- Agency theory misconceives the motivations of managers

- Agency theory ignores the diversity of investment institutions and interests

- Agency theory debilitates managers and corporations, and ultimately weakens economies

- Agency achieves the opposite of its intended effect (Stout 2012; Clarke 2014; Lazonick 2012, 2014; Aglietta and Reberioux 2005)

\section{TEAM PRODUCTION THEORY}

In recent decades many theories of corporate governance have developed that have attempted to complement or displace agency theory including institutional theory, resource dependence theory, stewardship theory, and stakeholder theory, and each has enjoyed varying degrees of support at different times. However one theorisation of corporate governance has experienced less interest in the business schools, but due to its origin in the nexus of contracts literature has received more attention from legal scholars, and that is the adaption of team production theory by Margaret Blair and Lynn Stout (1999). In this director primacy model the firm is viewed as a team production, defined as a complex productive activity involving multiple parties where the resulting output is neither separable nor individually attributable. 
In adaptation of the nexus of contracts theory Blair and Stout consider shareholders as only one of the parties that make a contribution to the firm, and effectively are not the only residual claimants of the firm (Blair \& Stout, 2001). Other groups, including employees, creditors, managers, and government, make contributions to ensure the enterprise will succeed (Kaufman \& Englander, 2005; Stout, 2002; Clarke 1998). The assets created are generally firm specific and, once committed to team production, cannot be withdrawn and sold elsewhere for their full value. Blair and Stout provide an expansive adaption of the original theoretical framework of Alchian and Demsetz (who themselves did not use the concept of 'nexus of contract' though it is closely associated with their work). For Blair and Stout team production theory with the board of directors serving as a 'mediating hierarchy' between the different interests provides a sound foundation for conceiving of the corporation in both law and practice:

"We believe, however, that our mediating hierarchy approach, which views public corporation law as a mechanism for filling in the gaps where team members have found explicit contracting difficult or impossible, is consistent with the "nexus of contracts" approach to understanding corporate law. The "nexus of contracts" view of the firm holds that relationships in the firm should be understood as an intertwined set of relationships between parties who agree to work with each other in pursuit of mutual benefit, even though not all the relationships that comprise a firm are necessarily spelled out in complete "contracts." It might perhaps be more informative to think of corporations, and hierarchical governance structures within corporations, as institutional substitutes for contracts, just as property rights are an institutional substitute and necessary precondition for contracts. Nevertheless, we locate the mediating hierarchy model of the public corporation within the nexus of contracts tradition because in the model, team members voluntarily choose to submit themselves to the hierarchy as an efficient arrangement that furthers their own self-interests." (Blair and Stout 1999:254)

\section{FIGURE 2}

\section{Berle and Means Model of Ownership and Control}


As Figure 2 demonstrates Blair and Stout have reformulated the Alchian and Demsetz approach to a nexus of contracts around the wider stakeholder relationships that exist in the business enterprise. While agency theory and shareholder primacy focus simply on the nexus between shareholders (principals) and directors (agents), the Blair and Stout conception of team production theory recognizes the significance and contribution of all with an interest in the success of the company including employees, customers, suppliers, creditors, and government (Blair 2005). At the centre of this constellation of relationships and interests is the mediating hierarch of the board of directors who negotiate effective outcomes in pursuit of the success of the business. Compared to the stark and binary assumptions of agency theory, Blair and Stout's team production theory conceives of much of the complexity of contemporary business activity, and the demands upon boards of directors and managers in securing performance.

To maintain the viability and innovation of businesses, managers are required to focus on their profit model (the entire focus of agency theory); but also upon developing the configuration of their business network, structure and processes; creating their products and production systems; and enhancing their services, channels, brands and customer engagement (Keeley et al 2013). Managers are used to being measured in their performance across this array of complex activities by hundreds of performance indicators, and are required to maintain continuous improvement in almost all of these indicators simultaneously if they are to compete effectively in the market. For agency theorists to reduce this complex and demanding existence of professional managers to the single metric of shareholder value is at best naïve, and at worst distorting and destabilising in the interpretation of business reality and orientation.

As the mediating hierarch in Blair and Stout's team production theory, the board of directors has to negotiate not only the conformance functions of monitoring and accountability that the agency theorists are focused upon, but the performance functions of providing strategic direction and a policy framework if the business is to succeed (Figure 3). If boards neglect the commitment and investment in strategic development of the company then paralysis and decline can quickly set in, though if aggressive strategy is pursued without a framework of monitoring and accountability then recklessness may take hold. In their insistent emphasis on the delivery of shareholder 
value, agency theorists emphatic attention is upon value extraction, and they routinely neglect the processes of value creation.

\section{FIGURE 3}

\section{Framework for Board Duties and Activities}

\section{VALUE FOR ALL PARTIES?}

As Margaret Blair contends, in the US directors have both the authority and the responsibility, without any change in corporate law, to consider the interests of all of the participants in the corporate enterprise in order to try to find the outcome that creates value for all parties (2012:69). However this responsibility is confounded by the realities of corporate practice. To take as an example, the recent experience of Apple, currently the most successful corporation in the US in terms of market capitalization, revenues, product design and brand. In 2013 Apple Corporation possessed in excess of $\$ 140$ billion in cash and liquid assets, probably the greatest hoard of any corporation in history (accumulated on the backs of over 1 million Chinese workers in assembly plants often deprived of pay, and frequently deprived of sleep, while Apple maintained up to 40 per cent returns while holding down costs on its supplier Foxconn).

Meanwhile, in response to pressure from the New York based Greenlight hedge fund Apple agreed to disburse dividend payments of $\$ 100$ billion over the following three years, and subsequently under pressure from the hedge fund raider Carl Icahn, Apple further increased this proposal for a massive disbursement of funds to shareholders (without any further commitment, other than those which had secured only modest improvements, to remedying Apple's appalling record of labour standards in China). When the CEO of Apple Tim Cook was hauled before the US Senate Permanent Subcommittee on Investigations to explain the systemic avoidance of corporation tax by Apple and other US corporations by parking tens of billions in overseas tax havens rather than repatriating the funds, his response was to call for a tax holiday to enable corporations to return their profits at a fraction of the standard corporate tax rate. This 
did not enamour the Senate since there was significant evidence that previous tax holidays for US corporations had not seen the funds utilised for business and employment development, but in paying dividends, share buy-backs, executive stock options and paying down debt (Marples and Gravelle 2011). Here is where the logic of shareholder primacy and the discipline of shareholder value leads when progressed through global value chains to factories in emerging economies: even the most successful corporation neglects the labour standards of a million young workers, and avoids paying taxes, while disbursing hundreds of billions of dollars to shareholders, and in the process loses much of the capacity to invest in innovation, and the design and development of new product technologies and new production processes.

Yet, while engaging in a considered way in this consistently irresponsible behaviour, boards of directors of US corporations clearly believe they are carrying out their duties as prescribed by corporations law, and are indeed legally constrained to do this. In fact there is no reference to any duty to deliver shareholder value in US corporate law, or in the corporate law of any other country (Blair 2012). Corporate law around the world sensibly states that it is the duty of directors to pursue the best interests of the company, and it is this interpretation that has been sustained in common law in many significant judgements in the courts. (There is a lingering definitional issue of who or what the company' is that directors are pursuing the best interests of, and often reference to the 'members' of the company. However though this may refer to the general body of shareholders over time, there is no injunction upon directors to pursue the immediate interests of shareholders, or the interests of particular shareholders. Nor are directors prevented from taking into account the interests of other stakeholders in the company. In fact the translation of shareholder rights into property rights by the agency theorists is quite bogus, since shareholders do not 'possess' any of the assets of the company (which are owned by the company). All shareholders posses is their shares, which give them certain rights such as attendance at the AGM, voting for directors, and receipt of dividends, but in no other sense allow any form of 'control' over the company. (Indeed if they did have such control, chaos would inevitably quickly occur, as professional managers business decisions were continuously over-ruled) (Stout 2012; Weinstein 2012; Blair 2005; 2012). 


\section{What Should be the Legal Rule With Respect to Directors' Duties?}

Many have argued for clarification of the legal duties of company directors, and in 1998 the Modern Company Law Review in the UK deliberated on these issues at length. Should company law :

- Require directors and senior managers to act by reference to the interests of all stakeholders in the corporate enterprise, according primacy to no particular interests including those of shareholders (mandatory pluralism)?

- Permit (but not require) directors \& senior managers to act by reference to the interests of all stakeholders, according primacy to no particular interests including those of shareholders (discretionary pluralism)?

The most radical of these models is the mandatory pluralist model creating a multifiduciary duty requiring directors and managers to run the company in the interest of all those with a stake in its success, balancing the claims of shareholders, employees, suppliers, the community and other stakeholders (UK BERR 2006; Parkinson 1993). After much debate it was the discretionary pluralism model that emerged clearly in the UK 2005 Companies Act section 172 (1):

"A director of a company must act in a way that he considers, in good faith, would be most likely to promote the success of the company for the benefit of its members as a whole, and in doing so have regard (amongst other matters) to -

(a) The likely consequences of any decision in the long term

(b) the interests of the company's employees

(c) the need to foster the company's business relationships with suppliers, customers and others

(d) the impact of the company's operations on the community and the environment

(e) the desirability of the company maintaining a reputation for high standards of business conduct, and 
(f) the need to act fairly between the members of the company."

The passage of this landmark redefinition of directors duties caused considerable interest around the word. Not only in the UK but in the US also this controversial new clause was trumpeted as a remarkable innovation in company law, the UK government claiming that the provision:

\footnotetext{
"Marks a radical departure in articulating the connection between what is good for a company and what is good for society at large" (DTI, June 2007) How the government interpreted the new clause was elaborated in the 2005 White Paper: "The basic goal for directors should be the success of the company for the benefit of its members as a whole; but that, to reach this goal, directors would need to take a properly balanced view of the implications of decisions over time and foster effective relationships with employees, customers and suppliers, and in the community more widely. The Government strongly agrees that this approach, which [is] called 'enlightened shareholder value', is most likely to drive long-term company performance and maximise overall competitiveness and wealth and welfare for all" (DTI 2005).
}

In Australia the potential of changing corporate law and directors duties was considered at this time in two Parliamentary inquiries by the Corporations and Markets Advisory Committee (CAMAC) and Parliamentary Joint Committee on Corporations and Financial Services (PJC). In Australia the Corporations Act 2001 does not provide an explicit legal duty that is owed by corporations and their directors to society, creditors, employees, company group, and individual shareholders. In practice, however, it is accepted the duty to act in the interests of the company may not be distinct from the interests of other stakeholders and this appreciation is leading to the development of an "Environment, Social and Governance" (ESG) theme in board management. In this context both inquiries rejected the need to change company law, and insisted that existing law permitted a wide definition of directors' duties:

“... A well managed company will generally see it as being in its own commercial interests, in terms of enhancing corporate value or opportunity, or managing 
risks to its business, to asses and, where appropriate, respond to the impact of its activities on the environmental and social context in which it operates.

Companies that fail to do so appropriately may jeopardise their commercial future" (CAMAC 2006).

"Companies that embrace the concept of corporate responsibility are realizing that the long-term financial interests of a company are not 'mutually exclusive' with acting fairly in the interests of stakeholders (other than shareholders)" (PJC 2006).

Many in Australia regarded this refusal to change the law as a missed opportunity, both to clarify the law, and to propel the growing movement towards greater corporate social and environmental responsibility. However in the UK the practical influence of the new legislation has proved modest compared to the ideals that inspired it. A survey of law firms at the time of legislation discovered that most were agnostic concerning whether section 172 might alter the outcomes of directors' decisions in the course of doing business (Loughrey et al 2008). In fact the UK revisions of directors duties have achieved little more than rebalancing the interpretation of directors duties back to the common law interpretation, before the shareholder primacy movement had caused a deeply flawed and unbalanced definition of directors duties to become salient. Meanwhile the practical exigencies of running a company in highly a financialized market environment, made it more difficult than ever to pursue the newly enlightened interpretation of directors duties in the UK or elsewhere.

Directors might have a new and more inclusive duty enshrined in the UK Act, but they remained entirely immersed in a political economy of financial institutions, relationships and expectations which they normally feel impelled to respect. These influences continuously shape and form directors values and behavior, as Lipton, Mirvis and Lorsch (2009) argue,

"Short-termism is a disease that infects American business and management and boardroom judgment. But it does not originate in the boardroom. It is bred in the 
trading rooms of the hedge funds and professional institutional investment managers who control more than $75 \%$ of the shares of most major corporations."

Redmond argues "we are at a stage where directors are permitted to take different stakeholder interests into account but only to the point that this can be argued to be good for long-term shareholder wealth" (Redmond 2013) It would be hard for directors to make decisions that treat the well-being of employees or the environment as the primary cause for action (unless based on other legal obligations under employment or environmental law). As Marshall and Ramsay (2013) state, "the extension of duties of directors has not been attended by the extension of rights for stakeholders"

\section{Financialized and Dehumanized Corporations?}

A cruel paradox that while we have been working back towards a broader and more inclusive definition of directors duties, and corporations themselves have been at pains to profess new found responsibilities, the practical realities of corporate existence and impact have often become more stark. Financial imperatives have driven a relentless pursuit of shareholder value, while the very concept has been exposed as narrow and damaging (Dore 2008; David 2009; Krippner 2005; 2012; van der Zwan 2013). This process of the cumulative financialisation of economies, corporations and society has been typified as encompassing:

- The ascendancy of shareholder value as a mode of corporate governance;

- The growing dominance of capital market financial systems over bank-based financial systems;

- The increasing political and economic power of a particular class grouping: the rentier class for some (Hilferding 1985);

- The explosion of financial trading with a myriad of new financial instruments;

- A pattern of accumulation in which profit making occurs increasingly through financial channels rather than through trade and commodity production (Krippner 2005; 2012); 
- The increasing role of financial motives, financial markets, financial actors and financial institutions in the operation of the domestic and international economies (Epstein 2005; van der Zwan 2013).

The impact of financialization is greatest among US corporations and was highlighted by Michael Porter in his research for the US Council on Competitiveness on Capital Disadvantage: America's Failing Capital Investment System (1992), with Porter explaining America's failure to compete effectively with European and Japanese corporations in the 1970s and 1980s, even in domestic markets, on the highly liquid but unstable US financial markets, compared to the more stable finance and governance of their overseas competitors. Bill Lazonick (1991; 2009) has completed a series of major research programs on the myths of the market economy and the failure of US capital markets to provide support for innovation in business in any sustainable way. Lazonick provides extensive evidence of four central elements driving the increasing financialization of US corporation: maximising shareholder value; the continuous payment of high share dividends; regular large scale share buy-backs by corporations; and high executive stock options (Lazonick 2012; 2014).

It was through a hollowing-out of the social responsibility of business that the US business corporation emerged as primarily a financial instrument. In this new financialized, dematerialized, and dehumanized corporate world, agency theory could be purveyed as the primary theoretical explanation, and shareholder value as the ultimate objective with impunity. In turn these new conceptions of the theory and objective of the firm became vital ingredients in the further financialization of corporations, markets and economies (Weinstein 2012). Lazonick (2011) records how financialization impacted upon the leading sectors of American industry: U.S. information technology companies, which led the world in 1990s innovation (Microsoft, IBM, Cisco, Intel, Hewlett-Packard), "spent more (much more except Intel) on stock buybacks than they spent on R \& D on 2000-2009."

As non-financial corporations have become increasingly drawn into a financial paradigm, they have less capital available for productive activity despite increasing 
profits from financial activity. A combination of the accumulation of debt and the volatility of asset prices has increased systemic risk, leading to the increasing intensity of boom-bust cycles (Becker 2010). These financial pressures are translated into the operations of corporations through the enveloping regime of maximising shareholder value as the primary objective. Agency theory has provided the rationale for this project, prioritising share-holders above all other participants in the corporation, and focusing corporate managers on the release of shareholder value, incentivised by their own stock options. In turn this leads to an obsessive emphasis on financial performance measures, with increasingly short-term business horizons. However, as financial gains are realised they are not reinvested in advancing the corporation's productive activity, but distributed to shareholders in dividend payments and share buy-backs (Lazonick 2012). While enriching executives and shareholders, corporations' innovative and productive future is threatened by the increasing impact of financialisation.

More critically "in the 2007/2008 global financial crisis, the financial firms (Citigroup, Merrill Lynch, Lehman Brothers, Wachovia, Washington Mutual, Fannie Mae, to name a few), many of whom failed, had previously used up precious reserves in order to fund stock buybacks, which in turn made already over-compensated executives even wealthier. Why did senior executives willingly diminish the financial strength and resilience of major corporations in this reckless way?" Lazonick (2011).

\section{The Continuing Reverberations of the Global Financial Crisis}

The relentless search for returns, regardless of the consequences, embodied in the pursuit of shareholder value was at the heart of the causes of the global financial crisis, and the continuing reverberations that are occurring. The self-interest and irresponsibility inherent in the practice of pursuing shareholder value reached its zenith with the reckless excesses of the global financial crisis. William Bratton and Michael Wachter (2008) relate the activities of financial sector firms in the years and months leading to the financial crisis of $2007 / 08$ :

"For a management dedicated to maximizing share-holder value, the instruction manual 
was clear: get with the program by generating more risky loans and doing so with more leverage. Any bank whose managers failed to implement the [high-risk strategy] got stuck with a low stock price. ... Unsurprisingly, its managers labored under considerable pressure to follow the strategies of competing banks."

The global financial crisis and its aftermath consisted of multiple and compounding failures in financial markets, institutions, regulation and governance (Clarke 2010, 2014; Becker et al 2010; Rajan 2010; Phillips 2010; Dunbar 2011; Akerlof and Schiller 2009; Das 2011; Sorkin 2009; Cohan 2009; Johnson and Kwak 2010). The 'animal spirits' unleashed in unfettered securities markets, massive incentivisation of risk taking and leverage, and the abandonment of effective governance and ethical commitments occurred in a regulatory vacuum. Governments were convinced that lightening the burden of regulation was the means to promote more dynamic financial markets and business development. The realisation of the consequences of unchecked systemic risks has prompted national governments and international agencies into a major series of regulatory reforms and interventions in financial markets and institutions, the effect of which remains to be discerned.

At a conference of corporate lawyers, investors, and regulators at the Columbia University Millstein Centre for Corporate Governance in June 2013 there were many indications that traction has not yet been achieved in the reform of the structure, orientations and behavior of the international financial community. The US Investment Banks (Strategically Important Financial Institutions) (SIFIs) have grown even larger since the financial crisis due to further consolidation in the industry following the crisis. The enormous wave of regulation from the G20, Basel Bank of International Settlements, and the passage of Dodd-Frank in 2010 have not changed the banks in any substantial and meaningful way. They Wall Street banks are now larger and more remote than before, and continue business as usual, and have not fundamentally changed their behaviour, leading Elizabeth Warren the campaigning US Senator to describe them as "Too big to fail, Too big to manage, Too big to regulate, and Too big to jail." 
There is a profound paradox that after two decades of corporate governance reform, governments and corporations remain fully engaged in the governance challenges posed by the transformation of markets, operations and technologies in the finance sector. "We have not yet fully understood the causes of the last financial crisis, and not begun to prepare for the next one." (Douglas Arner, HKU, 2013). The Dodd-Frank Wall Street Reform Act in US is still being implemented (828 pages, 398 rules, running to 14,000 pages, with every page being wrestled over by the lobbyists of the big banks). Though passage was finally achieved in December 2013 of the 882 page Volker Rule, intended to update the Glass-Stegall (27 pages long) separation of investment banking and retail banking, (preventing banks speculating with depositors funds, knowing the state will bail them out if they fail), the outcome of this legislative initiative remains in doubt. As Justin O'Brien comments on this tortured legislative process: "Ironically, flawed legislative framing, the complexity of Dodd-Frank, and the glacial pace of implementation enable the very defects in the financial sector regulation that legislators seek to remedy. The Volcker Rule, which restricts proprietorial trading, is an obvious example. A clear rule has transmogrified into a complex implementation process, informed by waves of exceptions that undercut legislative intent and undermine regulatory authority" (O’Brien 2014:383).

Any belief the considerable efforts by government to rescue and reform financial institutions and markets would lead to sustained stability and security in the sector, was rudely dispelled in a prolonged sequence of bank scandals and market failures in the years following the financial crisis. The banking crisis segued into a sovereign debt crisis in Southern Europe with governments facing challenges in funding their activities. This was quickly followed by seismic eruptions in the mainstream financial institutions with the revelations surrounding the LIBOR rate fixing. A total of $\$ 10$ trillion in loans and $\$ 350$ trillion in derivatives world-wide were indexed to LIBOR. As the US Financial Stability Oversight Council highlighted:

"Recent investigations uncovered systemic false reporting and manipulations of reference rate submissions dating back many years... This misconduct was designed to either increase the potential profit of the submitting firms or to convey a misleading picture of the relative health of the submitting banks. These actions were pervasive, 
occurred in multiple bank locations around the world, involved senior bank officials at several banks, and affected multiple benchmark rates and currencies, including LIBOR, EURIBOR, and the Tokyo Interbank Offered Rate (TIBOR). Each of the banks that faced charges engaged in a multi-year pattern of misconduct that involved collusion with other banks" (2013:137)

This rate manipulation pre-dated the crisis, and had continued long after the government support and intervention in the banking sector following the financial crisis, revealing how constricted any ostensible change in governance and ethics within the banks actually was. After a major inquiry into Barclay's involvement in the Libor raterigging, subpoenas to JPMorgan, Deutsche Bank, Royal Bank of Scotland Group, HSBC, Citigroup, and UBS, all of the banks settled for fines amounting to billions of dollars with the Department of Justice and CFTC in the United States, and the FSA in the United Kingdom. The Salz Review on Barclay's exposed the "gaps between Barclay’s publicly articulated values and its business practices" (2013:11). Antony Jenkins the new CEO of Barclays admitted in the 2012 Annual Report: "For the past 30 years, banking has been progressively too aggressive, too focused on the short term, too disconnected from the needs of our customers and clients, and wider society and we lost our way." The UK Parliamentary Commission on Banking Standards (2013) stated: "Too many bankers, especially at the most senior levels, have operated in an environment with insufficient personal responsibility... Remuneration has incentivised misconduct and excessive risktaking, reinforcing a culture where poor standards were often considered normal."

\section{The Kay Review of UK Equity Markets and Long-Term Decision Making}

In this context of the continuing ascendancy of shareholder value, and aggressive shorttermism, the UK Kay Review (2011-2012) was called to examine the mechanisms of corporate control and accountability provided by UK equity markets and their impact on the long term competitive performance of UK businesses, and to make recommendations. To inquire into whether the timescales considered by boards and senior management in evaluating corporate risks and opportunities, and by institutional 
shareholders and asset managers in making investment and governance decisions, match the time horizons of the underlying beneficiaries. And to consider whether the current functioning of equity markets gives sufficient encouragement to boards to focus on the long term development of their business. In the Interim Report of the Review Kay commented:

"We heard many references to the merits of liquidity, transparency, price discovery, and other intermediate objectives. While these objectives may be desirable, they are not achieved without cost, and must find their justification in the contribution they make to the fundamental goals of high performing companies and good risk adjusted returns for savers. ...Many respondents to this Review thought that equity markets have lost sight of these goals. For example, the Association of Chartered Certified Accountants (ACCA) observed that "it is sometimes forgotten that equity markets exist not solely to enrich speculators, market makers and intermediaries...It would seem fair to say that equity markets today serve the needs of the players in these markets better than they serve either those who put up the money or the businesses wanting finance to support growth."

Kay analysed this distinction between short term trading and long term investing. Highfrequency traders are driven by short-term market trends, and turn their portfolios over rapidly. Underlying performance is of less interest than immediate opportunity. In contrast, investors intent on holding assets for the long term will analyse a companies' prospects and underlying performance. Kay (2012: concludes "Equity markets work effectively for the corporate sector when they encourage, and do not impede, decisions which enhances the long-term competitive capabilities of the business." Yet recent advances in financial, computing and communications technologies have facilitated the dramatic reduction of the average holding period of equity: on the NYSE this has diminished from seven years in the 1950s to six months today. More worryingly as much as $70 \%$ of trading volume on the NYSE is performed by computer driven algorithms and is measured in milliseconds, and other exchanges are similarly overwhelmed. The concern is that the short-term emphasis of equity markets may have further intensified unproductive value extraction at the expense of sustainable value creation. 
The more impact short-term traders have in the market, the more volatile prices will be, as these become less rooted in the fundamentals of the value of corporations traded, as Andrew Haldane (2011) of the Bank of England has documented, citing a Chartered Financial Analyst (CFA) 2006 Symposium which concluded "The obsession with shortterm results by investors, asset management firms, and corporate managers collectively leads to the unintended consequences of destroying long-term value, decreasing market efficiency, reducing investment returns, and impeding efforts to strengthen corporate governance."

Indeed it can be argued that the key players in corporate governance, the institutional investors and the executives and directors running companies, are now so financially committed to the short term that there is little chance of Section 172 of the UK Corporation Act, or any similar legislation in other countries, changing their behavior. In this context, despite the high aspirations of some involved in the early work of revising UK company law, it is possible that section 172 and the accompanying business review in section 417 of the Act will simply amount to a directors' commentary that is a "self-serving and vacuous narrative rather than analytical material which is of genuine use" (Davies 2008:740) Yet long term innovation and investment performance requires attention to more than short-term financial metrics, and there are other critical and pressing reasons why corporations are now required to become more long-sighted and expansive in their purpose.

\section{Why Corporate Purpose, Corporate Governance and Director's Duties Will Change Now Towards Social and Environmental Sustainability}

In their analysis of team production Blair and Stout (unlike agency theorists) explicitly acknowledge the significance of external political influences upon the direction of corporations to which they must respond:

"A second lesson to draw from team production theory concerns the fundamentally political nature of the corporation. Scholarly and popular debates 
about corporate governance need to recognize that corporations mediate among the competing interests of various groups and individuals that risk firm-specific investments in a joint enterprise. .... Thus, future scholarship should explore in greater detail the internal and external political and economic pressures that affect the decision making process in firms." (Blair and Stout 1999:323)

Business is now faced by the greatest political and social challenge ever: how to stop the continuous and cumulative environmental despoliation of the planet before we reach the point of ecological disaster. Since the time of the industrial revolution industry has been deeply implicated in the emissions that have contributed to global warming, and now must be central to the achievement of zero carbon emissions and sustainable business enterprise. Tackling this challenge will necessitate a fundamental revision of corporate purpose, corporate governance and director's duties. How can we have confidence that this will be accomplished when so little has been achieved in the reformulation and enlightenment of directors duties after decades of effort up to this point? The answer is that we are now in the position of:

- Confronting an environmental and social challenge that is a universal problem unprecedented in human civilization;

- This is an urgent challenge and cannot be deferred or delayed;

- Corporations are a vital means to the solution of sustainability, but every other level of the economy and society will be involved including inter-governmental agencies, national governments, civil society and people.

No less a person than Henry Paulson, Secretary of the Treasury under George W. Bush, and the architect of the vast US rescue package during the global financial crisis, recently has called upon fellow Republicans to face up to their environmental responsibilities:

"I was Secretary of the US Treasury when the credit bubble burst, so I think it is fair to say that I know a little bit about risk, assessing outcomes and problemsolving... Looking back at the dark days of the financial crisis in 2008 , it is easy to see the similarities between the financial crisis and the climate challenge we now 
face. We are building up excesses (debt in 2008, greenhouse gas emissions that are trapping heat now). Our government policies are flawed (incentives for us to borrow too to finance homes then and encouraging the overuse of carbon-based fuels now)...And the outsize risks have the potential to be tremendously damaging (to a globalized economy then and the global climate now). Back then we narrowly avoided an economic catastrophe at the last minute by rescuing a collapsing financial system through government action. But climate change is a more intractable problem. The carbon dioxide we're sending into the atmosphere remains there for centuries heating the planet."

In response to conservative critics who highlight the high price of intervention, Paulson argues:

“...Our failure to act on the underlying problem is deeply misguided, financially and logically. In a future with more severe storms, longer fire seasons, and rising seas that imperil coastal cities, public funding to pay for adaptations or disaster relief will add significantly to our fiscal deficit and threaten our long-term economic security...A tax on carbon emissions will unleash a wave of innovation to develop technologies, lower the costs of clean energy and create jobs as we and other nations develop new energy products and infrastructure" (Paulson 2014).

Over the next 20 years businesses will be exposed to hundreds of environmental and social changes that will bring both risks and opportunities in the search for sustainable growth.

- Climate Change

- Volatile Fossil Fuel Markets

- Material Resource Scarcity

- Water Scarcity

- Population Growth

- Impact on resources of growing global middle class

- Growing Urbanisation

- Food Security

- Ecosystem Decline 
- Deforestation

(KPMG 2012)

To tackle these compounding problems corporations will be required to engage in a sustainable revolution just as profound as the industrial revolution in which we will move from a $19^{\text {th }}$ century focus on production, and a $20^{\text {th }}$ century focus on marketing and consumption, to a $21^{\text {st }}$ century focus on sustainability. But the integration of corporate governance and sustainability is still to be achieved: while corporate policy has become more sophisticated, implementation remains in its infancy. The reformulation of corporate purpose, corporate governance and directors' duties in the direction of greater environmental and social responsibility is now a matter of survival. 


\section{REFERENCES}

Akerlof, G. and Shiller, R. J. (2009) Animal Spirits: How Human Psychology Drives the Economy, and Why it Matters for Global Capitalism, Princeton University Press

Alchian, A.A. and Demsetz, H. (1973) "The property right paradigm", The Journal of Economic History, 33 (1)16-27.

Alchian, A. A. (1987) Property Rights, in, J. Eatwell, M. Milgate and P. Newman (eds.) The New Palgrave: A dictionary of economics. Reprints in, The New Palgrave. The Visible Hand, 1989, London and Basingstoke: The Macmillan Press

Aglietta M, Reberioux A. (2005) Corporate Governance Adrift: A Critique of Shareholder Value, Cheltenham: Edward Elgar

Becker, J., Jager, J. Leubolt, B. and Weissenbacher, R. (2010) "Peripheral Financialization and Vulnerability to Crisis: A Regulationist Perspective" (2010) Competition \& Change 14

Berle, A. A. Jr. (1932) For whom corporate managers are trustees: A note, Harvard Law Review, 45(8) (Jun.), 1365-1372; reproduced in T.Clarke (ed) Corporate governance: Critical Perspectives in Business and Management, Volume 1 The Genesis of Corporate Governance, London: Routledge, 76-83

Berle, A. A. Jr. and Means, G. (1932) The Modern Corporation and Private Property. New Edition, Brunswick (USA) and London (U.K.): Transaction Publishers

M. M. Blair (2005) Ownership and Control

Blair, M.M. and Stout,L. (2001) "Director Accountability and the Mediating Role of the Corporate Board, Washington University Law Quarterly, 79, 403.

Blair, M. M. and Stout, L. (1999) A Team Production Theory of Corporate Law, Virginia Law Review, vol. 85.

Blair, M. M. (2012) In the Best Interests of the Corporation: Directors Duties in the Wake of the Global Financial Crisis. In T. Clarke \& D. Branson (Eds.), The Sage Handbook of Corporate Governance (pp. 62-80). London: Sage

Bratton, W. W. and Wachter, M. L. (2008) Shareholder Primacy's Corporatist Origins: Adolf Berle and 'The Modern Corporation'”. Journal of Corporation Law, 34, 99, 2008; University of Pennsylvania, Institute for Law \& Economics Research Paper No. 07-24; Georgetown Law and Economics Research Paper No. 1021273. Available at SSRN: http://ssrn.com/abstract $=1021273$

Bratton, W., \& Wachter, M. (2010). The case against shareholder empowerment. University of Pennsylvania Law Review, 158, 653

Corporations and Markets Advisory Board (CAMAC) (2006) The Social Responsibility of Corporations Report, Australian Government, December 
Chandler, A. D. Jr. (1977) The Visible Hand, Managerial Revolution in American Business, Cambridge (Mass.): The Belknap Press of Havard University Press.

Clarke, T. (2015) International Corporate Governance, Second Edition, London: Routledge.

Clarke, T. (2014) The Impact of Financialisation on International Corporate Governance: the Role of Agency Theory and Maximising Shareholder Value, Law and Financial Markets Review, March 2014

Clarke, T. and Branson, D. (2012) Sage Handbook of Corporate Governance, London:Sage Clarke, T. (2010) Recurring Crises in Anglo-American Corporate Governance Contributions to Political Economy, 29(1)

Clarke, T. (2009). European Corporate Governance, London, Routledge

Clarke,T. and Clegg, S. (2000) Changing Paradigms: The Transformation of Management Knowledge for the $21^{\text {st }}$ Century, London: Harper Collins

Clarke, T. (1998) The Stakeholder Corporation: A Business Philosophy for the Information Age, 31(2) Long Range Planning - International Journal of Strategic Management, 31(2)

Cioffi, J. W. (2011) Fiduciaries, Federalization, and Finance Capitalism: Berle's Ambiguous Legacy and the Collapse of Countervailing Power, Seattle University Law Review, 34, 1081- 1120.

Coase, R. H. 1960 The Problem of Social Cost, Journal of Law and Economics, 3 (Oct.) 1-44 Cohan, W.D. (2009) House of Cards: How Wall Street Gamblers Broke Capitalism, Allen Lane

Das, S. (2011) Extreme Money: The Masters of the Universe and the Cult of Risk Portfolio Dodd, E. M. Jr. (1932) For Whom are Corporate Managers Trustees? Harvard Law Review, 45(7) (May)1145-1163; reproduced in T.Clarke (ed) Corporate governance: Critical Perspectives in Business and Management, Volume 1 The Genesis of Corporate Governance, London: Routledge, 61-75

Davis, G.F. (2009) Managed by the Markets: How Finance Re-shaped America (Oxford University Press, 2009

Dunbar, N (2011) The Devil's Derivatives, Harvard Business Review Press

Dore, R. (2008) Financialization of the Global Economy, Industrial and Corporate Change, 17,1097

Epstein, G.A. (2005) Financialization and the World Economy, Northampton MA: Edward Elgar 
Fligstein N. (1990) The Transformation of Corporate Control, Cambridge,Massachusetts: Harvard University Press

Fox,J. and Lorsch, J.A. (2012) What Good Are Shareholders? Harvard Business Review 90, 49

Galbraith, J. K. (1952) American Capitalism: The Concept of Countervailing Power, Boston: Houghton Mifflin Company.

Galbraith, J. K. (1967) The New Industrial State, Princeton and Oxford: Princeton University Press.

Ghoshal, S. (2005) Bad Management Theories are Destroying Good Management Practices, Academy of Management Learning and Education, 4 (1) 75-91

Haldane, G. (2011) The Short Long", 29th Société Universitaire Européene de Recherches Financières Colloquium 'New Paradigms in Money and Finance?', Brussels, May 2011, 3.

Henwood, D. (1998) Wall St. London/New York, NY: Verso

Hilferding, R. (1910). Finance Capital, A Study of the Latest Phase of Capitalist Development, Watnick, M. and Gordon, S. (eds.) (1981) London, RKP

Hilmer, F. and Tricker, R.I. (1991), An Effective Board, Company Director's Manual, Sydney: Athol Yeomans, Pearson/Prentice Hall.

Ireland, P. (2008) Financialization and Corporate Governance, Northern Ireland Legal Quarterly 60(1) 1-34

Ireland, P. (2005) Shareholder Primacy and the Distribution of Wealth" 68(1) Modern Law Review 49, 77.

Jensen, M. C. and W. H. Meckling (1976) Theory of the Firm: Managerial Behavior, Agency Costs and Capital Structure, Journal of Financial Economics, 3. Available at SSRN: http://ssrn.com/abstract $=94043$

Jensen, M. C. and W. H. Meckling (1978) Can the Corporation Survive?" Financial Analysts Journal, January/February, vol. 31, no. 1. Available at SSRN:

http://ssrn.com/abstract=244155

Johnson, S. and Kwak, J. (2010) 13 Bankers: The Wall Street Takeover and the Next Financial Meltdown, Pantheon Books, 2010

Kay, J. (2012) The Kay Review of UK Equity Markets and Long-Term Decision Making (Interim Report, UK Government)

Keay, A.R. (2011) Risk, Shareholder Pressure and Short-termism in Financial 
Institutions. Does Enlightened Shareholder Value Offer a Panacea? Law and Financial Markets Review, 5(6)

Keeley, L., Walters, H., Pikkel, R., \& Quinn, B. (2013) Ten Types of Innovation: The Discipline of Building Breakthroughs, Wiley

Krippner, G. (2012) Capitalizing on Crisis: The Political Origins of the Rise of Finance, Harvard University Press

Krippner, G. R. (2005). The Financialization of the American Economy, Socio-Economic

Review, Vol. 3(2): 173-208

Langlois, R. (2004) Chandler in a Larger Frame: Market, Transaction Costs and Organizational Form in History, Enterprise and Society, N5

Lan, L. L., \& Heracleous, L. (2010) Rethinking Agency Theory: The View from Law, Academy of Management Review, 35, 2, at 294.

Lazonick, W. (1991) Business Organisation and the Myth of the Market Economy, Cambridge University Press

Lazonick, W. (2009) Sustainable Prosperity in the New Economy? Business Organisation and High-Tech Employment in the United States, Upjohn Institute

Lazonick, W. (2012) In the Name of Shareholder Value: How Executive Pay and Stock Buy-Backs are Damaging the US Economy. In T. Clarke \& D. Branson (Eds.), The Sage Handbook of Corporate Governance (476-495). London: Sage.

Lipton, M., Mirvis ,T. and Lorsch, J. (2009) The Proposed 'Share- holder Bill of Rights Act of 2009, Harvard Law School Forum on Corporate Governance \& Financial Regulation (12 May 2009), accessible at : http://blogs.law.harvard.edu/ corpgov/2009/05/12/theproposed-\%e2\%80\%9cshareholder- bill-of-rights-act-of-2009\%e2\%80\%9d

Loughrey, J., Keay, A., and Cerioni, L. (2008) Legal Practitioners, Enlightened Shareholder Value and the Shaping of Corporate Governance, Journal of Corporate Law Studies, 8, 79

Marshall,S. and Ramsay,I. (2013) Stakeholders and Directors Duties: Law, Theory and Evidence, UNSW Law Journal, Forum 18(1)

Mitchell, R., O’Donnell, A., \& Ramsay, I. (2005) Shareholder Value and Employee Interests: Intersections of Corporate Governance, Corporate Law and Labor Law, Wisconsin International Law Journal, 23, 417

J. O'Brien (2014), Culture Wars: Rate Manipulation, Institutional Corruption, and the Lost Normative Foundations of Market Conduct Regulation, Seattle University Law Review, 37, 375-421

Parkinson, J. (1993) Corporate Power and Responsibility: Issues in the Theory of Company 
Law, Oxford University Press

Paulson, H. (2014) We US Conservatives Need to Recognise Climate Change and Find Market Solutions, The Observer, 29 June 2014

Phillips, K. (2009) Bad Money: Reckless Finance, Failed Politics and the Global Crisis of American Capitalism

Porter, M. (1992) Capital Disadvantage: America's Failing Capital Investment System, US Council on Competitiveness

Pye, A., \& Pettigrew, A. (2005) Studying Board Context, Process and Dynamics: Some Challenges for the Future. British Journal of Management, 16, S27-S38

Rajan, R. R. (2010) Hidden Fractures Still Threaten the World Economy, Princeton University Press

P Redmond (2013) Directors Duties and Corporate Social Responsiveness, UNSW Law Journal, Forum 18(1)

Salz, M. (2013) An Independent Review of Barclay's Business Practices, Salz

Segrestin, B., \& Hatchuel, A. (2011) Beyond Agency Theory, a Post-Crisis View of Corporate Law. British Journal of Management, 22, 484-499

Sorkin, A.R. (2009) Too Big to Fail Allen Lane

Stout, L. (2012a) "New Thinking on 'Shareholder Primacy"' 2(2) Accounting, Economics and Law: A Convivium, http://dx.doi. org/10.1515/2152-2820.1037

Stout, L. (2012b)The Shareholder Value Myth, Berrett-Koehler

UK Department of Business, Enterprise and Regulatory Reform (BERR) (2006) Company Law Review 1998-2000 http://

webarchive.nationalarchives.gov.uk/+/http://www.dti.gov. uk/bbf/co-act-2006/clrreview/page22794.html

UNEP (2014) Integrated Governance: A New Model of Governance for Sustainability, UNEP Financial Initiative, United Nations

US Financial Stability Council (2013) Annual Report 2013, Us Department of Treasury van der Zwan, N. (2013) Making Sense of Financialization, Socio-Economic Review 12, 99

Weinstein, 0. (2012) Firm, Property and Governance: From Berle and Means to the Agency Theory, and Beyond, Accounting, Economics and Law: A Convivium, 2(2) http://dx.doi. org/10.1515/2152-2820.1061 
Figure 1 The Evolution of Corporate Governance

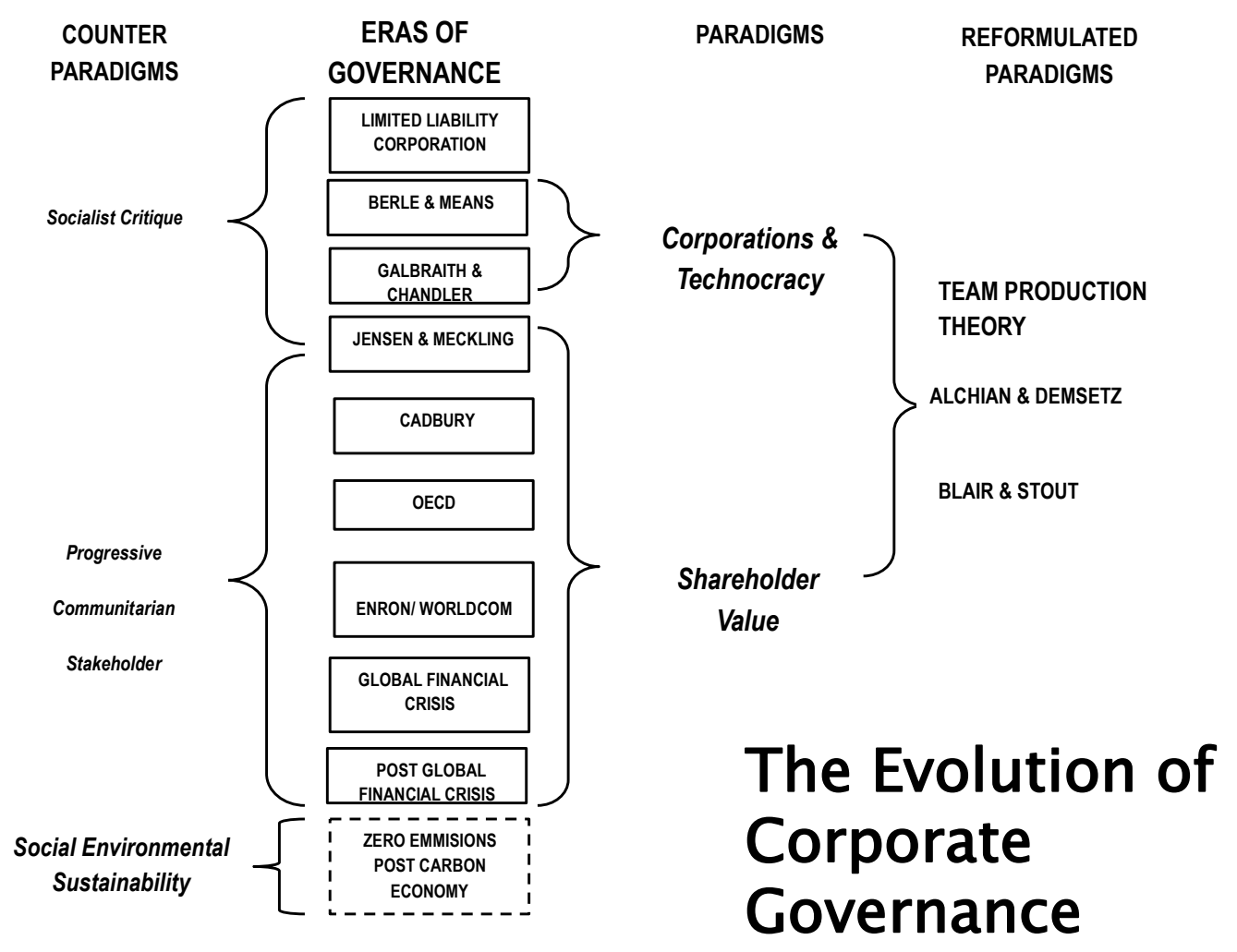


Figure 2 Berle and Means Model of Ownership and Control

Berle \& Means

Model of

Ownership and Control

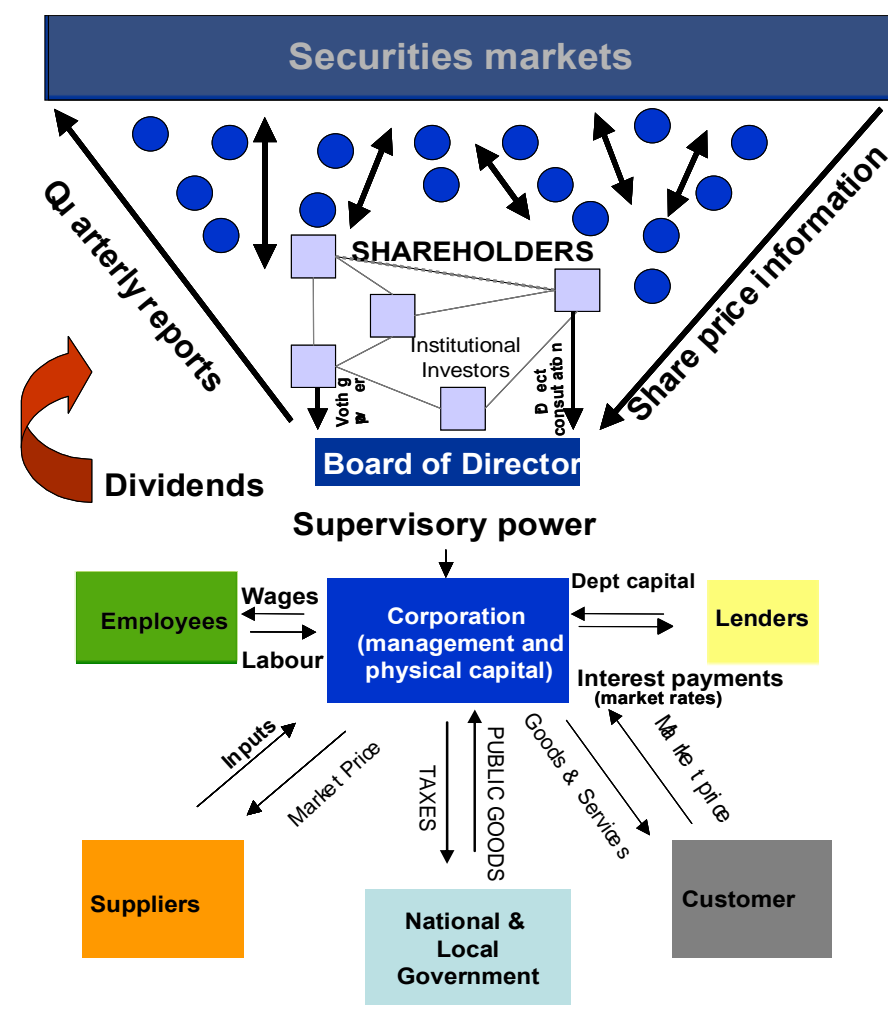

Adapted from: M. Blair, Ownership and Control (1995) 


\section{Figure 3 Framework for Board Duties and Activities}

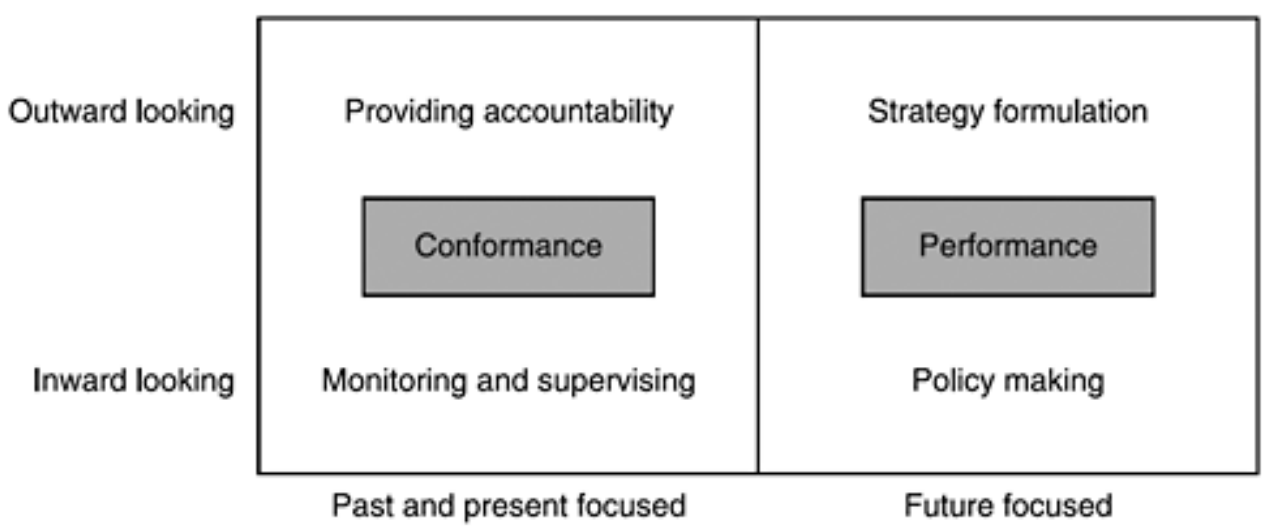

Source: Hilmer, F. and Tricker, R.I. (1991 